\title{
COMPARISON OF THE INDUCED PREOVULATORY LH DISCHARGE IN LACTATING AND DRY SHEEP DURING SEASONAL ANOESTRUS
}

\author{
J. PELLETIER AND J. THIMONIER \\ I.N.R.A., Station de Physiologie de la Reproduction, Nouzilly 37380, France
}

(Received 13th April 1972)

During seasonal anoestrus in Ile-de-France sheep, progestagen treatment with vaginal sponges associated with an intramuscular injection of PMSG induces oestrus and ovulation in dry and lactating females (42 days post partum).

The fertility after artificial insemination, expressed as the percentage of treated ewes which subsequently lamb, is lower in lactating ewes at the induced oestrus than in the non-lactating ewes $35 \%$ versus $70 \%$, Colas, Brice, Courot \& Cottier, 1971).

The present experiment was designed to investigate the effect of lactation on the induced preovulatory LH discharge since it may have an effect on fertility.

In April, during the period of seasonal anoestrus, twelve non-lactating ewes (Groups 1 and 2) and twelve lactating ewes (Groups 3 and 4) were submitted to the various treatments shown in Table 1 . The conditions of treatment for animals in Groups 1 and 3 were those normally used to induce lambing out of season, i.e. progestagen sponges were inserted on the 28th day after parturition and following removal, 12 days later, an intramuscular injection of PMSG was given (Thimonier \& Cognie, 1971). To avoid the excessive superovulation which sometimes results, the treatments were modified for Groups 2 and 4; in particular, an injection of oestradiol benzoate was administered to compensate for the decrease in the dose of PMSG (Day 13).

Table 1. Experimental treatments used to induce oestrus in dry and lactating Île-de-France ewes during anoestrus

\begin{tabular}{l|rr|cc}
\hline \multirow{2}{*}{ Treatment } & \multicolumn{2}{|c|}{ Dry ewes } & \multicolumn{2}{c}{ Lactating ewes } \\
\cline { 2 - 5 } & Group 1 & Group 2 & Group 3 & Group 4 \\
\hline FGA (mg) & 40 & 20 & 40 & 20 \\
PMSG (i.u.) & 600 & 400 & 800 & 400 \\
ODB ( $\mu$ g) & 0 & 50 & 0 & 50 \\
\hline
\end{tabular}

Six sheep per group. FGA: fluorogestone acetate administered for 12 days using vaginal sponges. The sponge impregnated with FGA was inserted into the vagina of lactating females on the 28th day after parturition. PMSG : intramuscular injection at the time of sponge withdrawal. ODB: intramuscular injection of oestradiol benzoate in oil $24 \mathrm{hr}$ after sponge withdrawal. 
Detection of oestrous started $24 \mathrm{hr}$ after the withdrawal of the vaginal sponges. Four 'entire' rams fitted with aprons were placed in a pen with the ewes and observed for $1 \mathrm{hr}$. The test was repeated after $2 \mathrm{hr}$, during which time the rams were removed from the pen. Three groups of four rams were used. As soon as a female was observed to stand for mounting, she was transferred to another pen and not tested further. The ewes were never mated.

At the end of each test period, blood samples were taken from all females by venipuncture from the jugular vein every $3 \mathrm{hr}$ for $48 \mathrm{hr}$. Plasma LH was assayed by radioimmunoassay (Pelletier, Kann, Dolais \& Rosselin, 1968). The quantity of LH released was estimated in arbitrary units by measuring the areas under the curves $\left(100 \mathrm{~mm}^{2}=12 \mathrm{ng} / \mathrm{ml} / \mathrm{hr}\right)$ representing in each case the plasma LH variations. This method was previously shown to be successful (Thimonier \& Pelletier, 1971). Finally, the number of ovulations was determined by endoscopy by counting the number of corpora lutea on the 10th day after withdrawal of the sponges.

All females, with the exception of one in Group 3, came into oestrus; the interval between sponge withdrawal and onset of oestrus was significantly shorter in non-lactating ewes than in lactating animals $(34.7 \pm 0.79$ versus $38.9 \pm 0.89, P<0.01)$; in neither case did the injection of oestrogen alter the onset of oestrus.

The mean numbers of ovulations in Groups 1 to 4 were $3 \cdot 8 \pm 1 \cdot 28,2 \cdot 0 \pm 0 \cdot 52$, $3.0 \pm 0.31$ and $2 \cdot 0 \pm 0 \cdot 44$, respectively; even though the treatment used in Groups 2 and 4 did not produce a significant decrease in ovulation rate, there was a tendency towards a reduced level $(0.05<P<0.1)$.

In all females which came into oestrus, a peak of LH was detected in the blood. Table 2 shows the mean areas under the curves describing the release of LH.

Table 2. Mean areas of LH peaks for dry and lactating Île-de-France ewes during seasonal anoestrus

\begin{tabular}{|c|c|c|c|c|}
\hline & \multicolumn{2}{|c|}{ Dry ewes } & \multicolumn{2}{|c|}{ Lactating ewes } \\
\hline & Group I & Group 2 & Group 3 & Group 4 \\
\hline $\begin{array}{l}\text { Individual group } \\
\text { Mean areas } \\
\text { (in } \mathrm{mm}^{2} \pm \text { S.E.M.) }\end{array}$ & $3459 \pm 501$ & $4334 \pm 600$ & $2318 \pm 478$ & $2704 \pm 808$ \\
\hline $\begin{array}{l}\text { Pooled group } \\
\text { Mean areas } \\
\text { (in } \mathrm{mm}^{2} \pm \text { S.E.M.) }\end{array}$ & \multicolumn{2}{|c|}{$3898 \pm 328$} & \multicolumn{2}{|c|}{$2550 \pm 332$} \\
\hline
\end{tabular}

Abscissa: $10 \mathrm{~mm}=3 \mathrm{hr}$. Ordinate: $10 \mathrm{~mm}=4 \mathrm{ng} \mathrm{LH} .100 \mathrm{~mm}^{2}=12 \mathrm{ng} / \mathrm{ml} / \mathrm{hr}$.

The discharge of $\mathrm{LH}$ induced in the lactating ewes was only $65 \%$ of that in the non-lactating females, a difference which is highly significant $(P<0.01)$. The standard errors of the observed means are in both cases approximately $10 \%$ of the means. This low coefficient of variation shows that the sampling technique has not led to a large amount of variation.

There was a difference between lactating and non-lactating ewes in both the maximum concentration of $\mathrm{LH}$ detected and in the duration of the discharge. 
The maximum concentration for the lactating and dry ewes were $79 \pm 14$ $\mathrm{ng} / \mathrm{ml}$ and $106 \pm 9 \mathrm{ng} / \mathrm{ml}$, respectively $(P \approx 0.05)$. The observed duration of LH release as revealed by sampling at 3 -hr intervals was $9 \mathrm{hr} 50 \mathrm{~min} \pm 50 \mathrm{~min}$ for the lactating ewes and $12 \mathrm{hr} 55 \mathrm{~min} \pm 1 \mathrm{hr}$ for the dry ewes $(P<0.05)$.

The present results agree with those obtained in several species, indicating that during lactation LH synthesis and release are reduced. In the rat, it has been demonstrated that milking decreases the hypophysial activity (Rothchild, 1960), the plasma LH level (McCann, Graves \& Taleisnik, 1961) and the hypothalamic LH-RF content (Minaguchi \& Meites, 1967). Similar conclusions have been deduced in the lactating sow from measurement of hypophysial LH content (Melampy, Henricks, Anderson, Chen \& Schultz, 1966; Crighton \& Lamming, 1969). Our results in the ewe show that the preovulatory induced LH release is also reduced during lactation.

Although the lower LH release in lactating ewes compared with dry ewes does not appear to limit the associated ovulation, it is possible that it is related to the reduced fertility of the lactating females.

\section{REFERENCES}

Colas, G., Brice, G. Courot, M. \& Cottier, M. (1971) L'insémination artificielle dans les plans d'intensification de la production ovine: état actuel et perspectives. Bull. tech. Inf. Ingrs Servs. agric. 257, 147.

Crighton, D. B. \& Lamming, G. E. (1969) The lactational anoestrus of the sow. The status of the anterior pituitary ovarian system during lactation and after weaning. 7. Endocr. 43, 507.

McGann, S. M., Graves, T. \& TAleisnik, S. (1961) The effect of lactation on plasma LH. Endocrinology, 68, 873.

Melampy, R. M., Henricks, D. M., Anderson, L. L., Chen, C. L. \& Schultz, J. R. (1966) Pituitary follicle stimulating hormone and luteinizing hormone concentrations in pregnant and lactating pigs. Endocrinology, 78, 801.

Minaguchi, H. \& Meites, J. (1967) Effects of suckling on hypothalamic LH-releasing factor and prolactin inhibiting factor, and on pituitary $\mathrm{LH}$ and prolactin. Endocrinology, 80, 603.

Pelletier, J., Kann, G., Dolais, J. \& Rosselin, G. (1968) Dosage radioimmunologique de l'hormone lutéinisante plasmatique chez le mouton. Mise au point de la technique de dosage. C.r. hebd. Séanc. Acad. Sci., Paris, D, 266, 2291.

RotнсніLD, I. (1960) The corpus luteum-pituitary relationship: the association between the cause of luteotrophin secretion and the cause of follicular quiescence during lactation; the basis for a tentative theory of the corpus luteum-pituitary relationship in the rat. Endocrinology, 67, 9.

Thimonier, J. \& Cognie, Y. (1971) Accélération des mises-bas et conduite d'élevage chez les ovins. Bull. tech. Inf. Ingrs Servs. agric. 257, 187.

Thimonier, J. \& Pelletier, J. (1971) Différence génétique dans la décharge ovulante (LH), chez les brebis de race Île-de-France relations avec le nombre d'ovulations. Amls Biol. anim. Biochim. Biophys. 11, 559. 